\title{
MicroRNA-145-5p suppresses fascin to inhibit the invasion and migration of cervical carcinoma cells
}

\author{
SHUFANG HE, GUIYUAN YU, KE PENG and SISUN LIU \\ Department of Gynecology, The First Affiliated Hospital of Nanchang University, Nanchang, Jiangxi 330006, P.R. China
}

Received January 30, 2020; Accepted August 20, 2020

DOI: $10.3892 / \mathrm{mmr} .2020 .11592$

\begin{abstract}
MicroRNAs (miRs) can affect the progression of cervical cancer (CC). The present study investigated the function of miR-145-5p in CC and demonstrated its association with fascin (FSCN1). The expression levels of miR-145-5p in $\mathrm{CC}$ tissues and cell lines were analyzed using reverse transcription-quantitative PCR, and its direct targets were explored using a luciferase reporter assay. The viability, migration and invasion of HeLa cells transfected with small interfering FSCN1 or with miR-145-5p mimics and inhibitors were analyzed using Cell Counting Kit-8 and Transwell assays. The expression levels of FSCN1 mRNA and protein were investigated using reverse transcription PCR and western blotting. miR-145-5p was downregulated in CC tissues and cell lines. Moreover, overexpression of miR-145-5p inhibited the migration, invasion and viability of HeLa cells. miR-145-5p directly targeted FSCN1, which regulated the suppressive functions of miR-145-5p in CC cells. Overall, miR-145-5p is a tumor suppressor gene and a promising target for $\mathrm{CC}$ treatment.
\end{abstract}

\section{Introduction}

Cervical cancer (CC), is one of the most common gynecological malignancies in females and has a high death rate worldwide (1). Each year, $>270,000$ females die as a result of cervical cancer, of which 53,000 are located in China (2). $\mathrm{CC}$ originates either from cervical intraepithelial neoplasia (CIN) or squamous intraepithelial lesions (3). Recently, the occurrence rates of $\mathrm{CC}$ have decreased due to novel screening, diagnostic and treatment techniques (4). However, a high number of females still develop and die from this disease every year (5). Hence, new therapeutic strategies and molecular diagnostic biomarkers for $\mathrm{CC}$ are required. MicroRNAs

Correspondence to: Dr Sisun Liu, Department of Gynecology, The First Affiliated Hospital of Nanchang University, 17 Yongwaizheng Street, Donghu, Nanchang, Jiangxi 330006, P.R. China

E-mail: liusisun656@163.com

Key words: cervical cancer, microRNA-145-5p, fascin, migration, invasion
(miRNAs/miRs) are a group of non-coding RNAs that are 22 nucleotides long, and can inhibit mRNA translation or catalyze mRNA cleavage to block the expression of target mRNAs (6). Therefore, miRNAs have become an area of interest in oncology research in recent years. Key events in the development of CC may involve the loss or acquired function of certain miRNAs (7). miR-145, a tumor suppressor in various types of cancer, is abnormally expressed in gastric, ovarian, breast, prostate and lung cancer (8-11). miR-145 overexpression can suppress human colon cancer SW620 cells (12). miR-145 regulates the biological function of tumor cells by regulating the expression levels of numerous downstream genes (13); to the best of our knowledge, however, there are no studies about the function of miR-145 in cervical cancer. Fascin-1 (FSCN1) is an actin-binding protein which is present in mesenchymal tissues, however, its expression levels are limited in adult epithelial cells (14). In the physiological and tumor environment, fascin proteins stabilize the formation of parallel actin bundles in cell protrusions, which represent the initial stage of cell migration (15). FSCN1, a direct target of miR-145 in esophageal cancer (16), is involved in a number of cancer processes in vivo (17). For example, FSCN1 suppresses epithelial mesenchymal transition (EMT) in human ovarian cancer cells (18). FSCN1 also suppresses tumors in gastric cancer (19). Moreover, miR-145 can inactivate CC cells by targeting FSCN1 (20). However, the molecular mechanisms underpinning the functions of miR-145-5p in CC are not clear.

The present study aimed to investigate the functional roles and molecular mechanisms of miR-145-5p in CC and to reveal the association between miR-145-5p and FSCN1 in CC.

\section{Materials and methods}

Tissue collection and cell culture. In total, 40 paired adjacent tissues (located $0.5 \mathrm{~cm}$ from the cancer lesions) and CC tissues were acquired from the First Affiliated Hospital of Nanchang University and were stored in liquid nitrogen prior to use. All patients provided written informed consent to participate.

ECT1/E6E7, HeLa and C33a cell lines were obtained from the Cell Bank of Type Culture Collection of the Chinese Academy of Sciences. These cells were incubated in DMEM (Gibco; Thermo Fisher Scientific, Inc.) and 10\% FBS (Gibco; Thermo Fisher Scientific, Inc.), penicillin (100 units/ml) and streptomycin $(100 \mu \mathrm{g} / \mathrm{ml})$ at $37^{\circ} \mathrm{C}$ and $5 \% \mathrm{CO}_{2}$. Approval was 
obtained from the Ethics Committee of the First Affiliated Hospital of Nanchang University.

Cell transfection. miR-145-5p mimics or inhibitors (100 nM) and FSCN1 small interfering (si)RNA (50 nM) (GenePharma Co., Ltd.) were transfected into HeLa cells cultured in 6-well plates (Corning, Inc.) at $75 \%$ confluence using Lipofectamine $300{ }^{\circledR}$ reagent (Invitrogen; Thermo Fisher Scientific, Inc.) at $37^{\circ} \mathrm{C}$ for $24 \mathrm{~h}$ based on the manufacturers' instructions. The sequences of siRNAs, mimics, inhibitors and controls are as follows: FSCN1 siRNA sense, 5'-GCUGCUACUUUG ACAUCGATT-3' and antisense, 5'-UCGAUGUCAAAGUAG CAGCTT-3'; scrambled siRNA sense, 5'-AUAUUCCUG CGAUAGCUCGTT-3' and antisense, 5'-CGAGCUAUCGCA GGAAUAUTT-3'; miR-145-5p mimics sense, 5'-GUCCAG UUUUCCCAGGAAUCCCU-3' and antisense, 5'-GGAUUC CUGGGAAAACUGGACUU-3'; miR-145-5p mimics control sense 5'-UUCUCCGAACGUGUCACGUTT-3' and antisense, 5'-ACGUGACACGUUCGGAGAATT-3'; miR-145-5p inhibitors sense, 5'-AGGGAUUCCUGGGAAAACUGGAC-3' and miR-145-5p inhibitors control sense, 5'-CAGUACUUUUGU GUAGUACAA-3'.

$R N A$ extraction and $R T-q P C R$. Total RNA from miR-145-5p mimics or inhibitors and FSCN1 siRNA-transfected HeLa cells was isolated using TRIzol ${ }^{\circledR}$ reagent (Invitrogen; Thermo Fisher Scientific, Inc.). Total RNA content was quantified spectrophotometrically, then cDNA was prepared with a RT kit (cat. no. RR037A; Takara Biotechnology Co., Ltd.) at $37^{\circ} \mathrm{C}$ for $15 \mathrm{~min}$ according to the manufacturer's instructions. miR-145-5p and FSCN1 expression levels were measured using reverse transcription-quantitative PCR (RT-qPCR) using an ABI PRISM 7500 sequence detection system (Thermo Fisher Scientific, Inc.) and SYBR Premix Ex Taq Master Mix (Takara Bio, Inc.). U6 and GAPDH were used as internal controls. The following primer pairs (Invitrogen; Thermo Fisher Scientific, Inc.) were used for the qPCR: miR-145-5p forward, 5'-GUC CAGUUUUCCCAGGAAUCCCU-3' and reverse, 5'-GGA UUCCUGGGAAAACGUGACUU-3'; U6 forward, 5'-CCC TGGCACCCAGCAC-3' and reverse, 5'-GCCGATCCACAC GGAGTAC-3'; FSCN1 forward, 5'-GGAGACCGACCAGGA GAC-3' and reverse, 5'-GATTGGACGCCCTCAGTG-3' and GAPDH forward, 5'-CAATGACCCCTTCATTGACC-3' and reverse, 5'-GACAAGCTTCCCGTTCTCAG-3'. A total of $0.5 \mu \mathrm{l}$ cDNA, $0.5 \mu \mathrm{l}$ forward primer, $0.5 \mu 1$ reverse primer, $2 \mu \mathrm{l}$ deoxyribonucleotide triphosphate mixture $(2.5 \mathrm{mM}), 0.5 \mu 1$

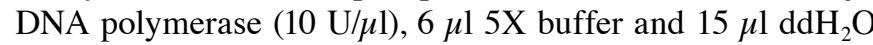
were subjected to 38 cycles at $95^{\circ} \mathrm{C}$ for $5 \mathrm{~min}, 95^{\circ} \mathrm{C}$ for $15 \mathrm{sec}$ and $56^{\circ} \mathrm{C}$ for $30 \mathrm{sec}$. miR-145-5p and FSCN1 expression were analyzed using the $2^{-\Delta \Delta \mathrm{Cq}}$ method (21).

Luciferase reporter assay. The 3'-untranslated region (3'-UTR) of FSCN1 was located using TargetScan (targetscan.org/vert_71/) was cloned into a pGL4-empty vector (Promega Corporation). HeLa cells were cultured in a 96-well plate $\left(2 \times 10^{4}\right.$ cells/well) and co-transfected with miR-145-5p mimics, inhibitors or negative control and the 3'-UTR vector using Lipofectamine ${ }^{\circledR} 3000$ (Invitrogen; Thermo Fisher Scientific, Inc.) with Opti-MEM (Thermo Fisher Scientific, Inc.). Subsequently, a mutant (Mut) 3'-UTR plasmid was generated at the binding sites for miR-145-5p (Promega Corporation). After $24 \mathrm{~h}$ of culture, the cells were lysed in radioimmunoprecipitation assay buffer with protease inhibitor cocktail (Roche Diagnostics Shanghai Co., Ltd.), and luciferase activity was detected using a dual luciferase reporter assay kit (Promega Corporation). Firefly luciferase activity was standardized to that of Renilla.

Cell Counting Kit (CCK)- 8 assay. The growth of HeLa cells was analyzed using a CCK-8 assay (cat. no. C0038; Beyotime Institute of Biotechnology.). In brief, cells in 24-well plates were cultured for $24 \mathrm{~h}$ and transfected with miR-145-5p mimics and inhibitors. Subsequently, transfected cells (100 $\mu \mathrm{l}, 1 \times 10^{5}$ cells/well) and CCK- 8 solution $(10 \mu \mathrm{l} /$ well) were added to 96 -well plates for $2 \mathrm{~h}$ of culture at $37^{\circ} \mathrm{C}$. Viable cells were measured with an Epoch microplate absorbance tester (BioTek Instruments, Inc.) at a wavelength of $450 \mathrm{~nm}$.

Migration and invasion assays. The migration and invasion of HeLa and ECT1/E6E7 cells were analyzed using Transwell chambers with $8.0-\mu \mathrm{m}$ pore size (Corning, Inc.). In brief, $1 \times 10^{5}$ transfected cells without FBS were seeded in the uncoated top chamber, and their migration or invasion was initiated by adding $20 \%$ FBS to the lower chamber for $24 \mathrm{~h}$. Meanwhile, transfected cells $\left(1 \times 10^{5}\right)$ were seeded into a chamber with an $8-\mu \mathrm{m}$ pore size pre-coated with BD Matrigel $^{\mathrm{TM}}$ Basement Membrane Matrix (BD Biosciences) and placed in a 24-well plate for $24 \mathrm{~h}$. These cells, along with the coated membranes, were then placed in the upper chamber and cultured for migration and invasion assays. These cells were dyed with $0.2 \%$ crystal violet for $15 \mathrm{~min}$ at $37^{\circ} \mathrm{C}$ (Beyotime Institute of Biotechnology) and washed with PBS. Images were captured and counted under an upright microscope (magnification, $\mathrm{x} 40$ ).

Western blotting. Total proteins were obtained using radioimmunoprecipitation assay buffer (cat. no. 89900; Invitrogen; Thermo Fisher Scientific, Inc.), and determined using a bicinchoninic acid kit (cat. no., P0010; Beyotime Institute of Biotechnology). Proteins $(50 \mu \mathrm{g})$ were separated using $10 \%$ SDS-PAGE. After membranes were blocked with $5 \%$ non-fat milk at $37^{\circ} \mathrm{C}$ for $1 \mathrm{~h}$, the membranes were incubated with primary antibodies against FSCN1 (1:1,200; cat. no. ab220195; Abcam) and GAPDH (1:2,000; cat. no: ab181602; Abcam), followed by HRP-conjugated goat anti-mouse IgG secondary antibody (1:2,000; cat. no. ab97040; Abcam) overnight at $4^{\circ} \mathrm{C}$. Finally, bands were visualized using a FluorChem imaging device (ProteinSimple). Band intensities were analyzed using ImageJ (version 1.45; National Institutes of Health).

Statistical analysis. All data were analyzed using SPSS 16.0 (SPSS, Inc.) or GraphPad Prism 5.0 (GraphPad Software, Inc.). $\chi^{2}$ or Fisher's exact tests were used to compare categorical variables as appropriate. Student's t-test, Mann-Whitney U test and one-way ANOVA with Tukey's post hoc test were used to compare continuous data. Results were expressed as mean \pm SEM. $\mathrm{P}<0.05$ was considered to indicate a statistically significant difference. 
Table I. Association between the expression of miR-145-5p and clinicopathological factors in patients with cervical cancer.

\begin{tabular}{|c|c|c|c|c|}
\hline \multirow[b]{2}{*}{ Variables } & \multirow[b]{2}{*}{ Patients $(n=40)$} & \multicolumn{2}{|c|}{ miR-145-5p expression } & \multirow[b]{2}{*}{ P-value } \\
\hline & & Low $(n=25)$ & $\operatorname{High}(\mathrm{n}=15)$ & \\
\hline Age (years) & & & & 0.874 \\
\hline$\leq 52$ & 22 & $14(56.0)$ & $8(53.3)$ & \\
\hline$>52$ & 18 & $11(44.0)$ & $7(46.7)$ & \\
\hline Tumor size $(\mathrm{cm})$ & & & & 0.078 \\
\hline$\leq 2$ & 28 & $15(60.0)$ & $13(86.7)$ & \\
\hline$>2$ & 12 & $10(40.0)$ & $2(13.3)$ & \\
\hline Differentiation & & & & 0.108 \\
\hline Well & 20 & $15(60.0)$ & $5(33.3)$ & \\
\hline Moderate, poor & 20 & $10(40.0)$ & $10(66.7)$ & \\
\hline Tumor grade & & & & 0.002 \\
\hline G1 & 17 & $5(20.0)$ & $12(80.0)$ & \\
\hline $\mathrm{G} 2+\mathrm{G} 3$ & 23 & $20(80.0)$ & $3(20.0)$ & \\
\hline Lymph node metastasis & & & & 0.013 \\
\hline No & 22 & $10(40.0)$ & $12(80.0)$ & \\
\hline Yes & 18 & $15(60.0)$ & $3(20.0)$ & \\
\hline
\end{tabular}

\section{Results}

Patient characteristics. The expression of miR-145-5p in $\mathrm{CC}$ patients with different clinicopathological features are summarized in Table I. miR-145-5p expression in both cancer and adjacent tissues was measured in each patient. The mean values of miR-145 expression levels in CC tissues were used as the cutoff values $(0.637)$. The samples were divided into high and low expression group, and then correlated with the clinicopathological characteristics of the cases. The cancer histology and differentiation data are shown in Table I. There are no significant differences found in clinicopathological factors, including age, tumor size and differentiation grade, between the low miR-145-5p expression group and high miR-145-expression group. However, there was a significant difference in tumor grade and lymph node metastasis between the miR-145-5p high and low expression groups.

miR-145-5p is downregulated but FSCN1 is overexpressed in $C C$. The clinicopathological results indicated that miR-145-5p expression is lower in patients with $\mathrm{CC}$ and associated with lymph node metastasis. Both miR-145-5p and FSCN1 expression in CC tissues and cell lines were analyzed. miR-145-5p expression was significantly lower in CC tissues and HeLa and C33a cells compared with the NC controls (Fig. 1A and B). Simultaneously, FSCN1 expression was significantly higher in $\mathrm{CC}$ tissues and HeLa and C33a cells compared with the $\mathrm{NC}$ controls (Fig. 1C-F). HeLa is a classic cell line in cervical cancer research and exhibited significant FSCN1 overexpression in the present study. Thus, HeLa cells were used for subsequent experiments. These results demonstrated that both decreased miR-145-5p expression and FSCN1 overexpression occurs in CC.

miR-145-5p directly targets FSCN1 in vitro. To investigate the effects of miR-145-5p downregulation and FSCN1 overexpression in CC, the probable target genes of miR-145-5p were identified using bioinformatic tests, which included FSCN1 (Fig. 2A). Dual-luciferase reporter assays indicated that miR-145-5p mimics significantly inhibited the luciferase activities of Mut FSCN1, but did not affect those of wild-type FSCN1 (Fig. 2B). Furthermore, transfection of miR-145-5p mimics and inhibitors significantly altered miR-145-5p expression compared with control (Fig. 2C). FSCN1 expression significantly decreased in HeLa cells treated with miR-145-5p mimics compared with control, while FSCN1 expression significantly increased in cells treated with miR-145-5p inhibitor compared with NC control (Fig. 2D-F) at both mRNA and protein levels. These results indicated that miR-145-5p directly targeted FSCN1.

miR-145-5p inhibits the viability, migration and invasion of HeLa cells. The function of miR-145-5p in CC cells was analyzed using Transwell and CCK-8 assays. miR-145-5p overexpression decreased HeLa cell viability, but decreased miR-145-5p expression significantly promoted HeLa cell viability compared with control (Fig. 3A). Moreover, miR-145-5p upregulation significantly suppressed HeLa cell migration compared with NC control, while miR-145-5p knockdown showed the opposite effect (Fig. 3B and C). Similar results were observed in invasion assays (Fig. 3D and E). These results demonstrated that miR-145-5p can inhibit the migration and invasion of $\mathrm{CC}$ cells. 
A

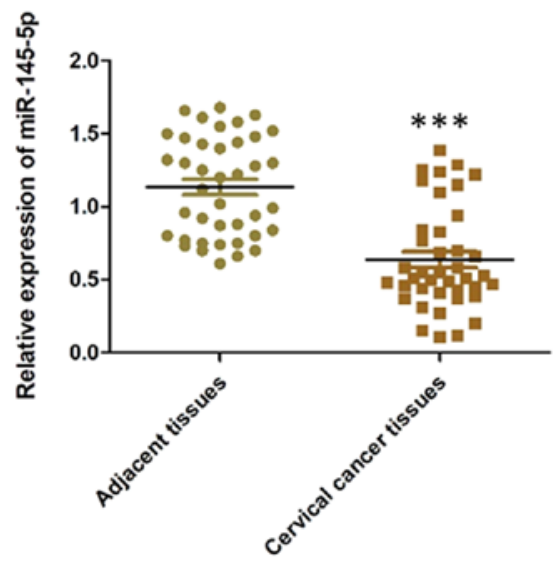

C

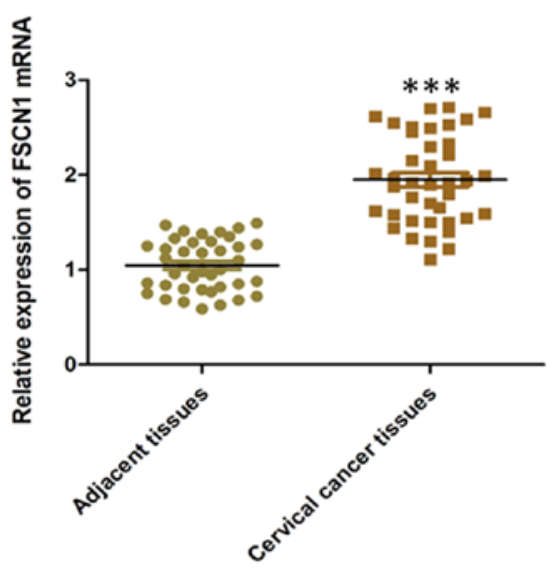

E

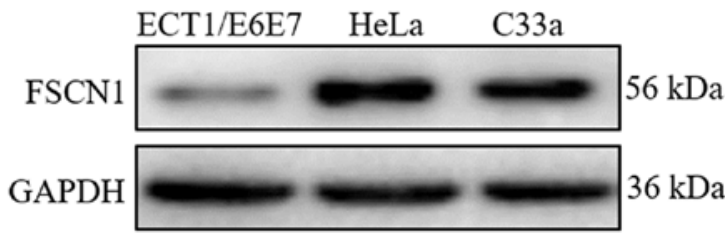

B

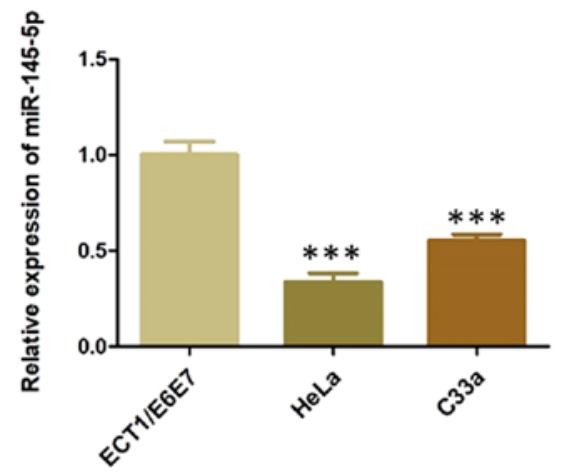

D

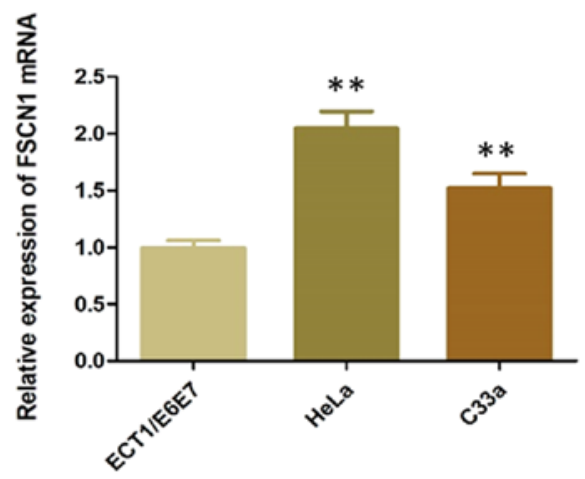

$\mathbf{F}$

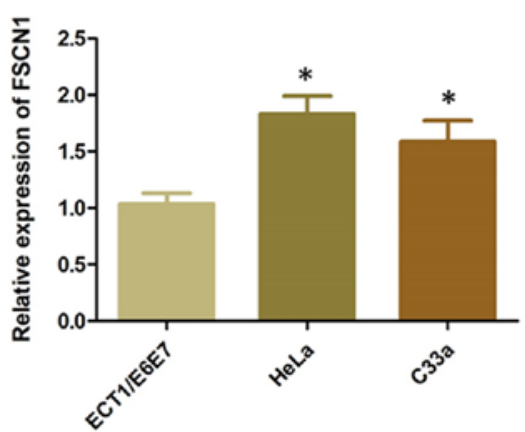

Figure 1. miR-145-5p and FSCN1 expression. (A) miR-145-5p expression was significantly lower CC tissues compared with the controls. (B) miR-145-5p expression was significantly downregulated in HeLa and C33a cells compared with ECT1/E6E7 cells. FSCN1 mRNA expression was increased in (C) CC tissues and (D) HeLa and C33a cell lines analyzed using reverse transcription quantitative-PCR. (E and F) FSCN1 protein levels were overexpressed in HeLa and C33a cells analyzed using western blotting. ${ }^{*} \mathrm{P}<0.05,{ }^{* *} \mathrm{P}<0.01$ and ${ }^{* * * *} \mathrm{P}<0.001$ vs. adjacent tissues or ECT/E6E7 cells. miR, microRNA; CC, cervical carcinoma; FSCN1, fascin.

ECT1/E6E7 viability, migration and invasion is regulated by $m i R-145-5 p$. ECT1/E6E7 is a normal cervical epithelial cell line and was used to assess the effects of miR-145-5p on tumor malignancy. The expression levels of miR-145-5p increased in miR-145-5p mimics-transfected ECT1/E6E7 cells (Fig. 4A) but decreased in miR-145-5p inhibitors-transfected ECT1/E6E7 cells compared with $\mathrm{NC}$ control. It was found that miR-145-5p overexpression significantly decreased the viability of ECT1/E6E7 cells (Fig. 4B), but the viability of ECT1/E6E7 cells transfected with miR-145-5p inhibitors increased compared with NC control. Meanwhile, miR-145-5p knockdown significantly promoted the expression of FSCN1 protein in ECT1/E6E7 cells; however, miR-145-5p overexpression demonstrated the opposite effect (Fig. 4C and D). In addition, the migration and invasion of ECT1/E6E7 cells significantly decreased following miR-145-5p overexpression (Fig. 4E-H). However, miR-145-5p knockdown significantly increased the migration and invasion of these cells.

ECT1/E6E7 cell metastasis is regulated by FSCN1 overexpression. FSCN1 siRNA was transfected into ECT1/E6E7 cells to investigate its function to the metastasis of ETC1/E6E7 cells. FSCN1 knockdown significantly decreased the expression of FSCN1 mRNA and protein compared with control and scrambled siRNA transfection (Fig. 5A-C). In addition, the migration and invasion of ETC1/E6E7 cells were significantly inhibited by FSCN1 


\section{A FSCN1 Mut 3'UTR 5'...CUGGgCGUGUAGUGUAACUGGAA... 3

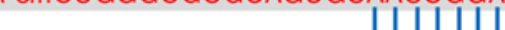 \\ has-miR-145-5p 3' ...UCCCUAAGGACCCUUUUGACCUG... 5 \\ FSCN1 Wt 3'UTR 5'...CUGGGCGUGUAGUGAAACUGGAC... 3'}

$\mathrm{B}$

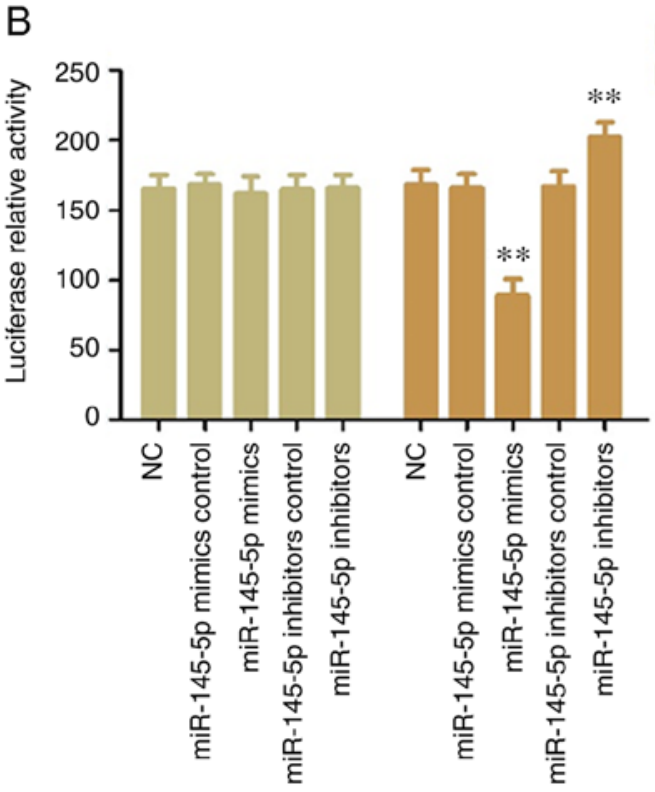

C
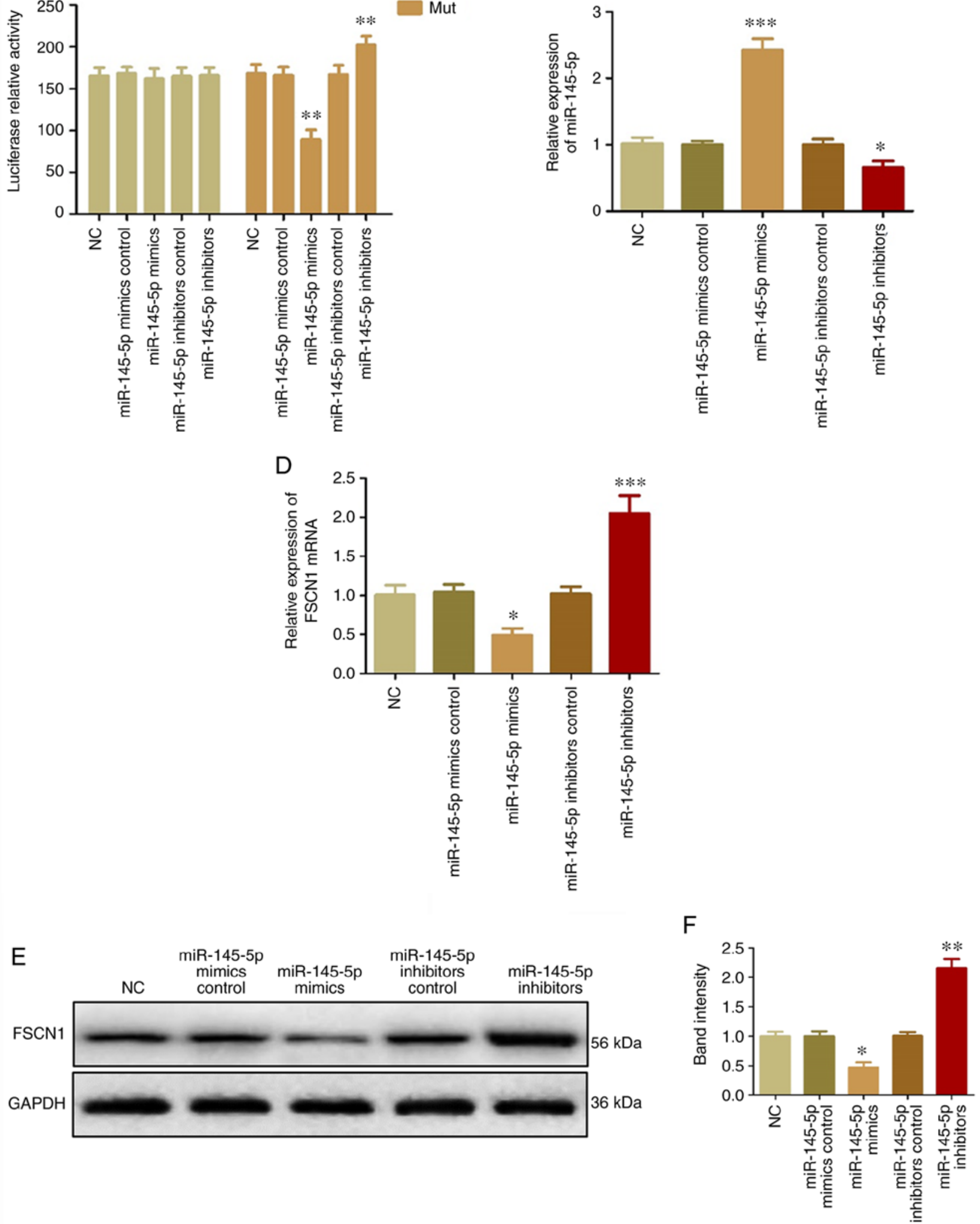

Figure 2. miR-145-5p directly targets FSCN1 in cervical cancer cells. (A) Binding sites between miR-145-5p and FSCN1. (B) Luciferase activities of Wt-FSCN1 mRNA in HeLa cells. (C) miR-145-5p expression in HeLa cells transfected with miR-145-5p mimics, inhibitors, mimics control or inhibitors control. FSCN expression in HeLa cells transfected with miR-145-5p mimics, inhibitors, mimics control or inhibitors control was detected at (D) mRNA and (E and F) protein levels. ${ }^{*} \mathrm{P}<0.05$ vs. $\mathrm{NC},{ }^{* *} \mathrm{P}<0.01$ vs. $\mathrm{NC}$ and ${ }^{* * *} \mathrm{P}<0.001$ vs. NC. miR, microRNA; FSCN1, fascin; Wt, wild-type; Mut, mutant; $\mathrm{NC}$, negative control. 


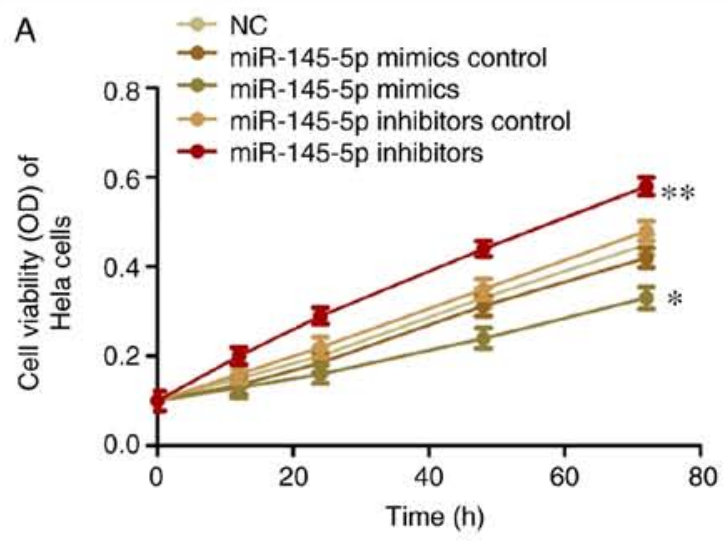

B

Migration

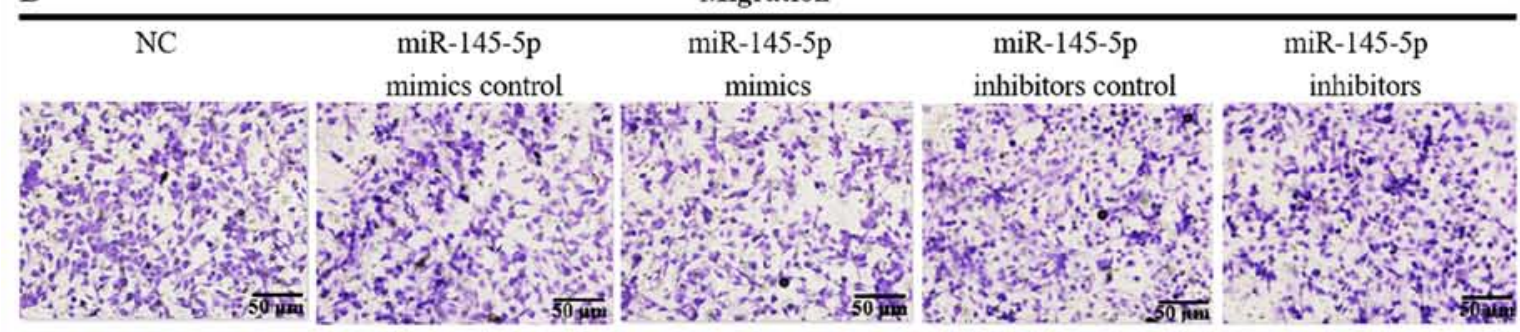

C

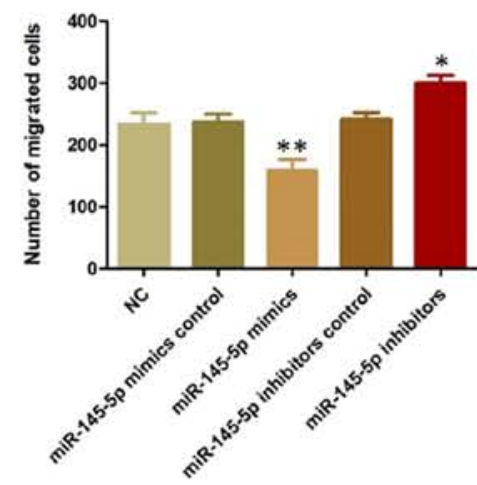

D

Invasion
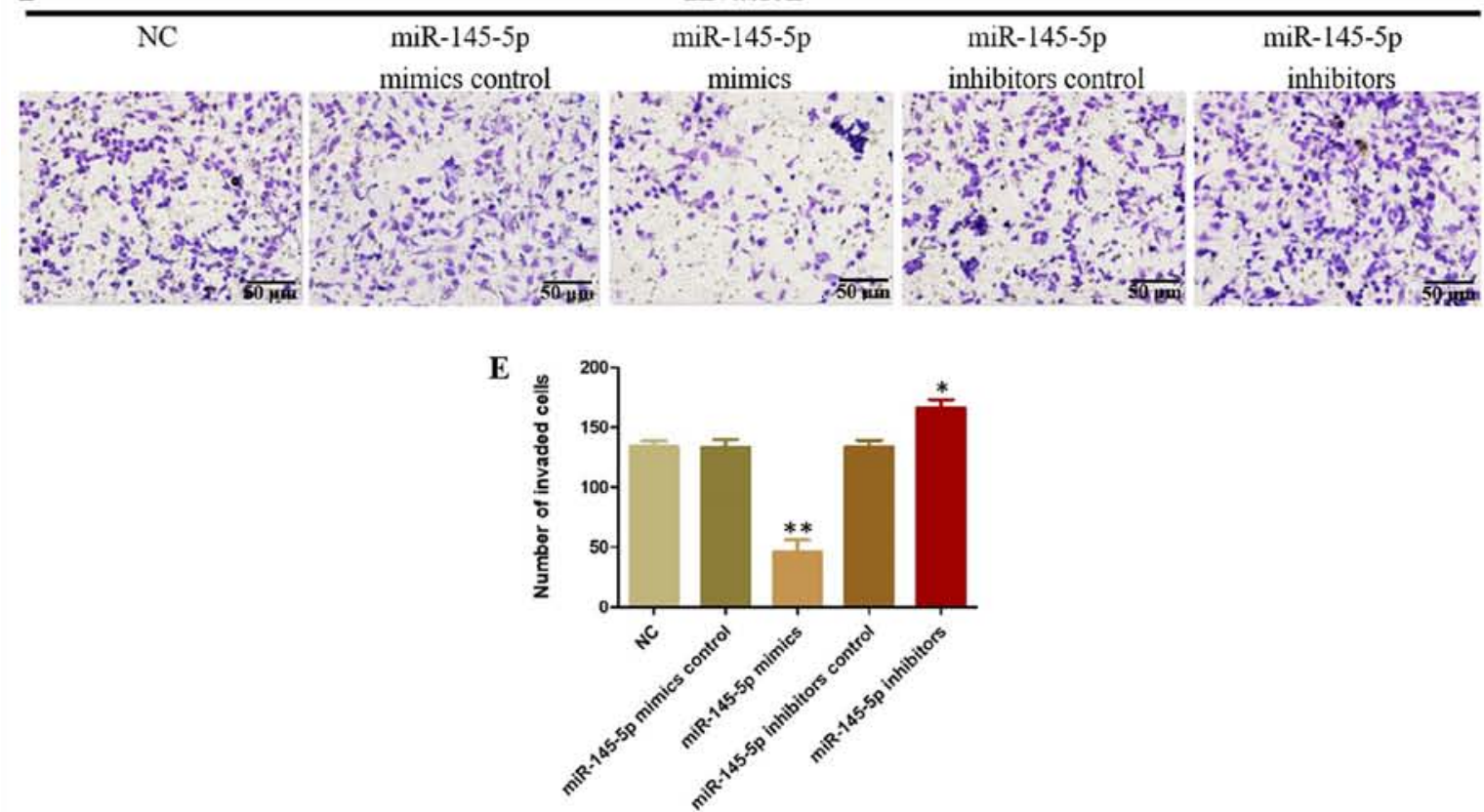

Figure 3. Tumor suppressing effects of miR-145-5p in cervical cancer. (A) The viability of HeLa cells transfected with miR-145-5p mimics, inhibitors, mimics control or inhibitors control were determined using a Cell Counting Kit-8 assay. (B and C) Migration of transfected HeLa cells analyzed using Transwell assays. (D and E) Invasion of HeLa cells analyzed through the overexpression and knockdown of miR-145-5p using Transwell assays. Magnification, $\mathrm{x} 40$. ${ }^{*} \mathrm{P}<0.05$ and ${ }^{* *} \mathrm{P}<0.01$ vs. NC. miR, microRNA; OD, optical density; NC, negative control. 

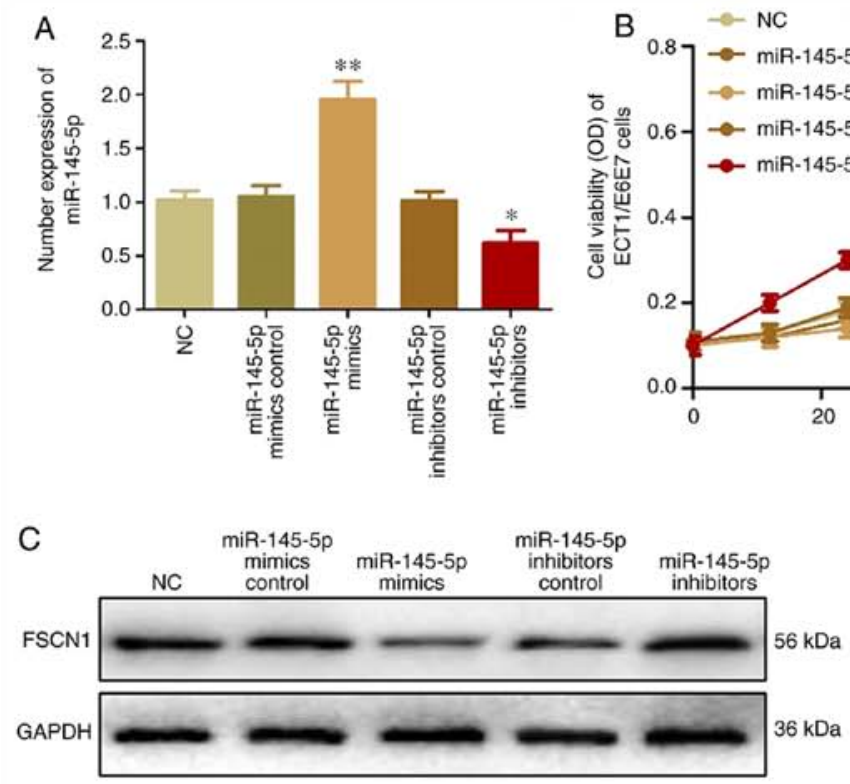

E
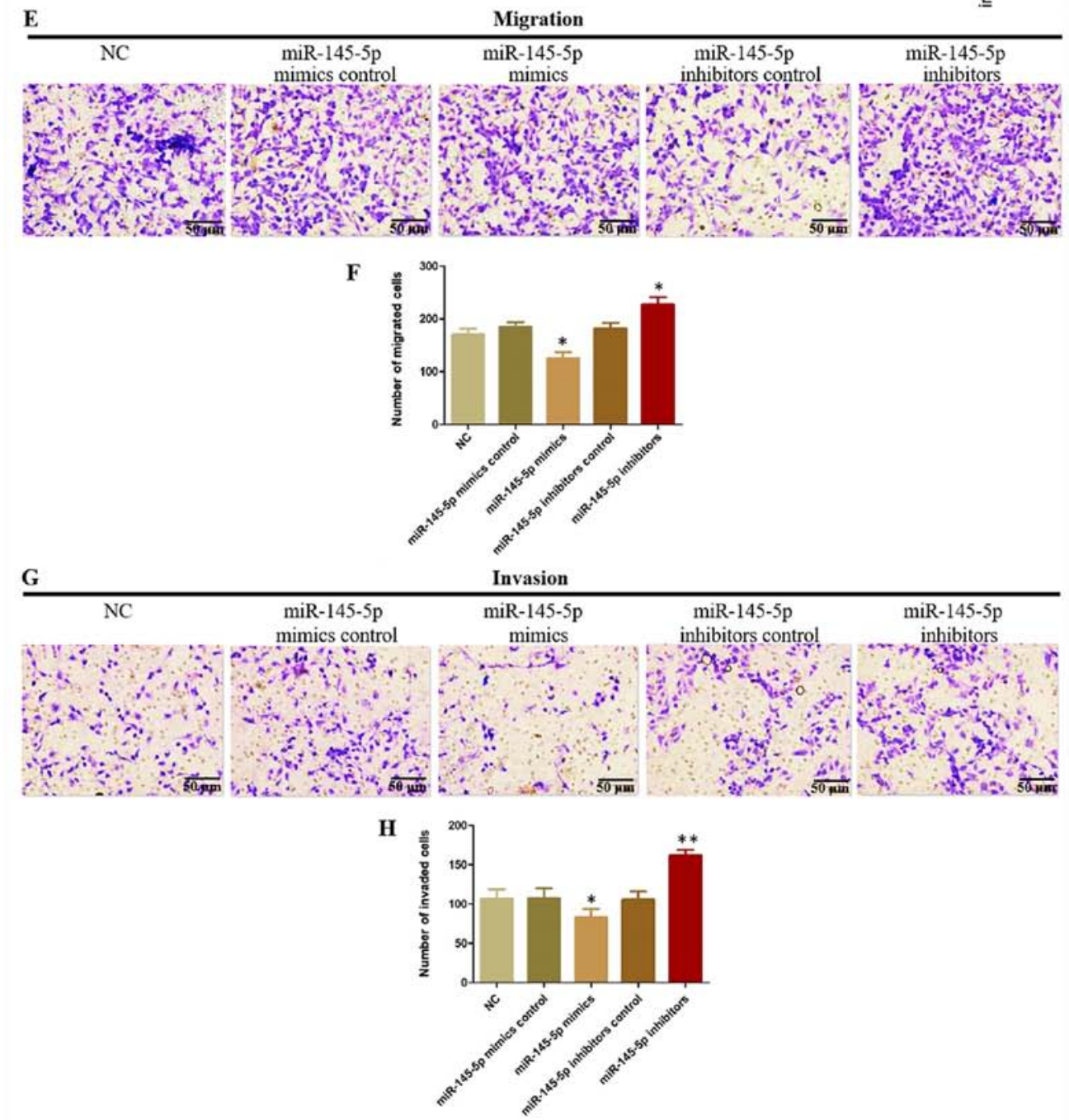
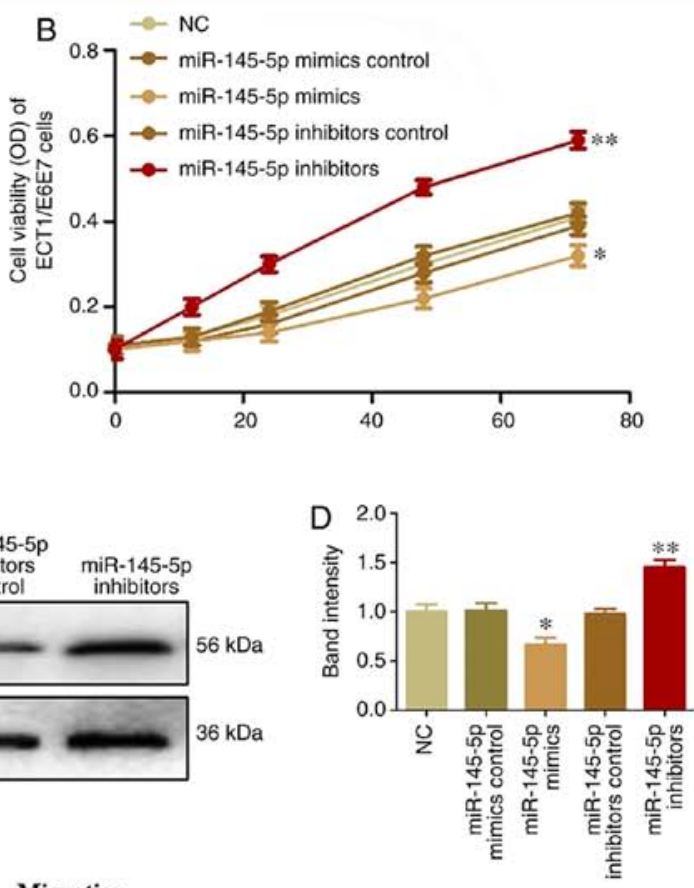

Invasion 


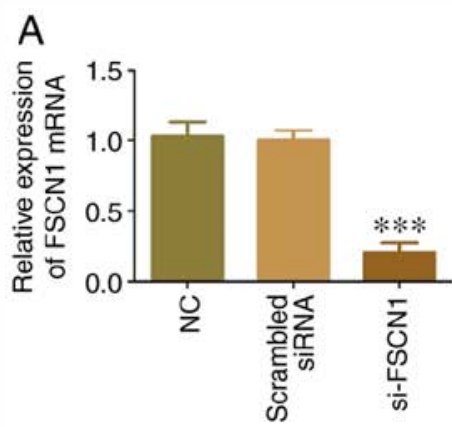

D

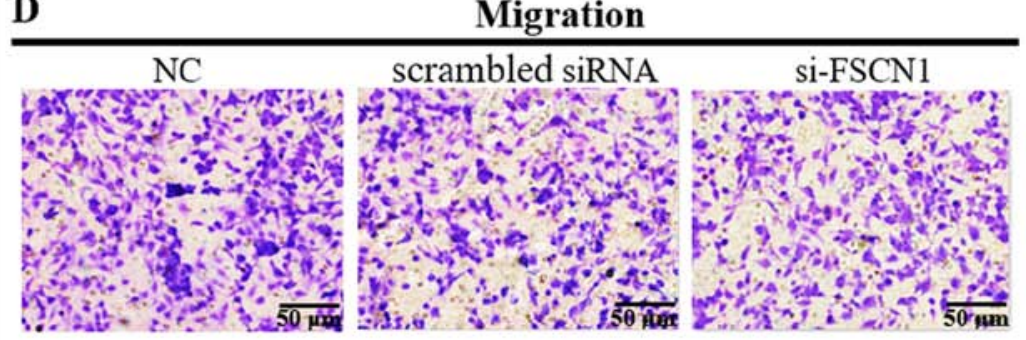

F
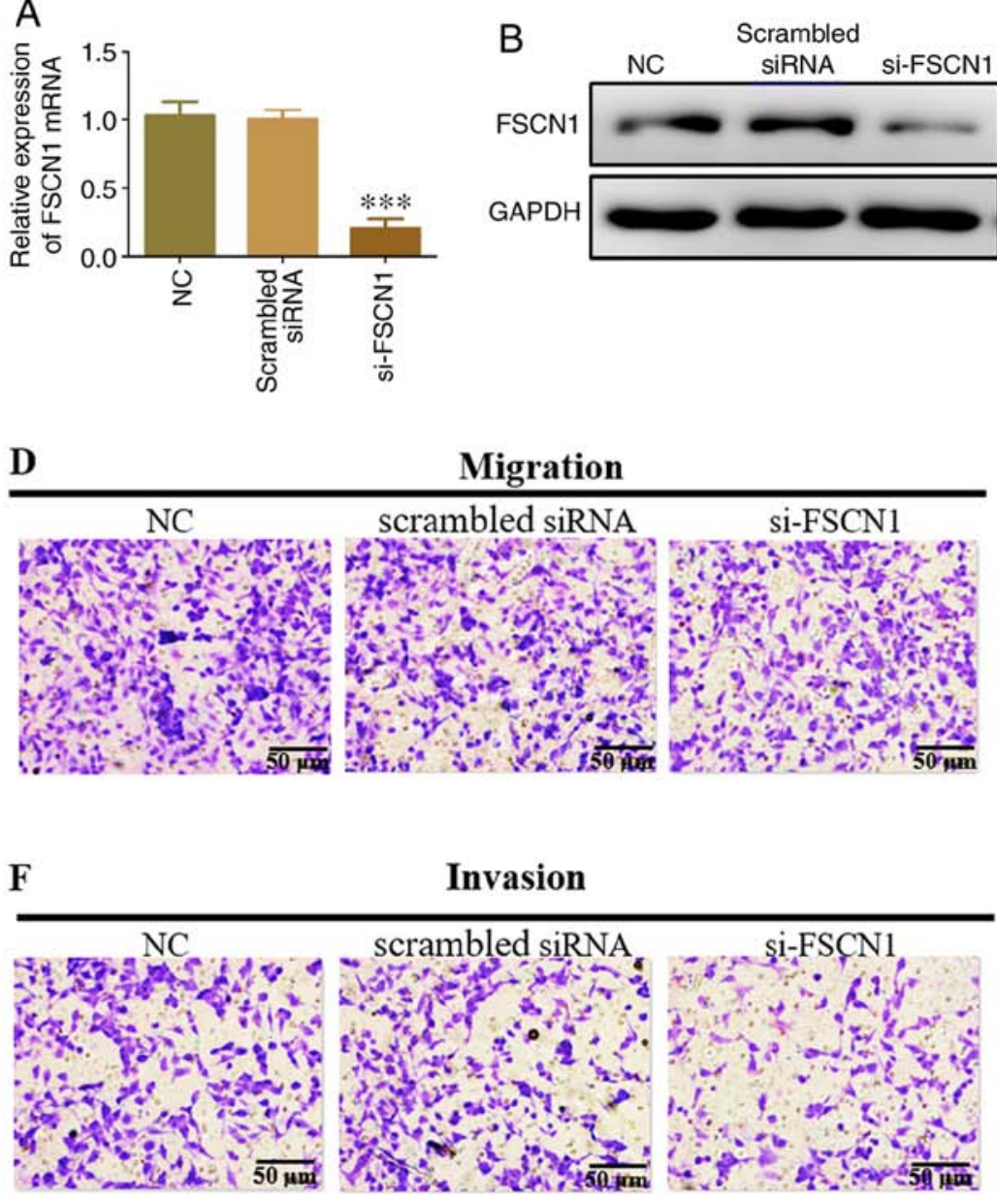
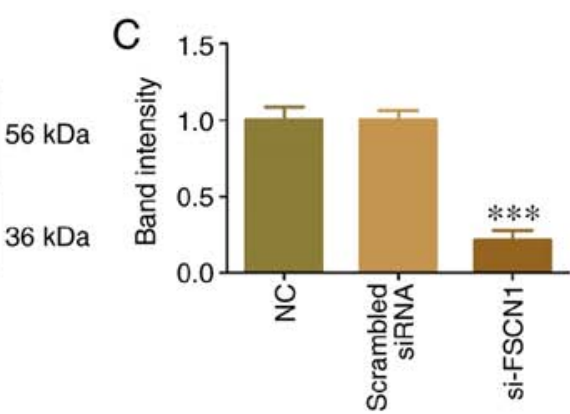

E

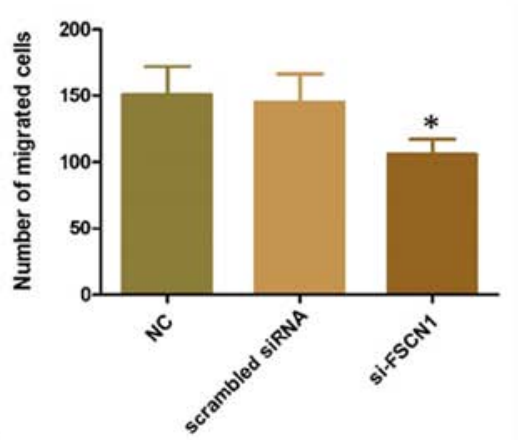

G

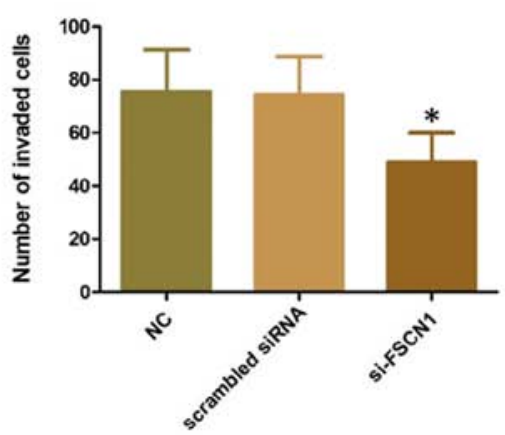

Figure 5. Migration and invasion of ECT1/E6E7 cells is suppressed by FSCN1 siRNA. FSCN1 expression at (A) mRNA and (B and C) protein levels were inhibited by FSCN1 siRNA in ECT1/E6E7 cells. The (D and E) migration and (F and G) invasion abilities of ECT1/E6E7 cells following knockdown of FSCN1 was analyzed using Transwell assays. Magnification, $\mathrm{x} 40$. ${ }^{*} \mathrm{P}<0.05$ and ${ }^{* * *} \mathrm{P}<0.01$ vs. NC. miR, microRNA; FSCN1, fascin; siRNA, small interfering RNA; NC, negative control.

siRNA (Fig. 5D-G). These findings indicated that FSCN1 exerted a tumorigenesis function in ECT1/E6E7 cells.

FSCN1 is overexpressed and stimulates the metastasis of CC. HeLa cells were transfected with FSCN1 siRNA to investigate the roles of FSCN1 in CC. FSCN1 mRNA and protein expression were significantly decreased relative to the controls and scrambled siRNA (Fig. 6A-C). In addition, FSCN1 siRNA inhibited the migration and invasion of HeLa cells (Fig. 6D-G), which were similar to the effects of miR-145-5p overexpression. These findings revealed that FSCN1 promoted tumorigenesis in CC.

FSCN1 influences the tumor-suppressive function of $m i R-145-5 p$. To confirm whether FSCN1 upregulation affected the inhibitory role of miR-145-5p on the migration and invasiveness of HeLa cells, an FSCN1 overexpression vector was transfected into HeLa cells containing miR-145-5p mimics. FSCN1 expression significantly increased in HeLa cells transfected with FSCN1 vector compared with control and empty vectors (Fig. 7A-C). Moreover, FSCN1 mRNA and protein expression significantly increased following co-transfection with miR-145-5p and FSCN1 expression vector (Fig. 7D-F). In addition, FSCN1 overexpression significantly inhibited the tumor-suppressing function of miR-145-5p on the migration and invasion of HeLa cells (Fig. 7G-J). These results indicated that FSCN1 overexpression attenuated the inhibitory functions of miR-145-5p in CC.

\section{Discussion}

miRNAs inhibit mRNA degradation or translation to regulate posttranscriptional expression of target genes (22). miRNAs are important regulators of tumor metastasis, including cell differentiation, migration and invasion (23). miR-145 is downregulated in multiple types of human cancer and functions as an important tumor suppressor (24). In addition, miR-145 is downregulated in laryngeal squamous cell carcinoma, and its overexpression inhibited the 


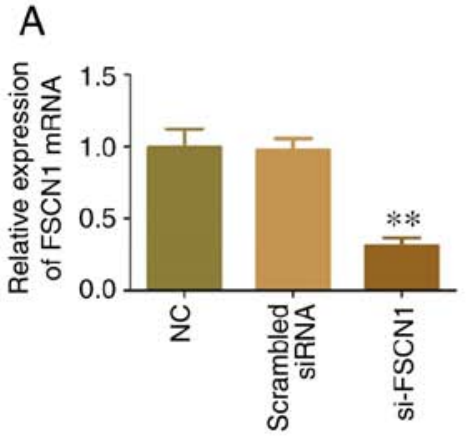

D

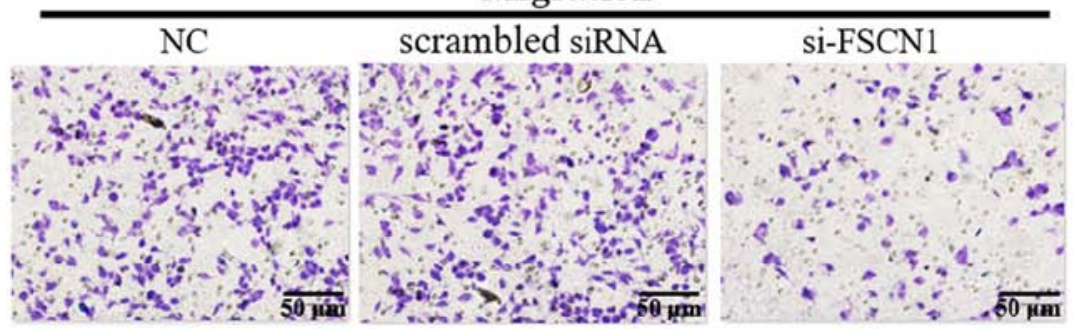

F

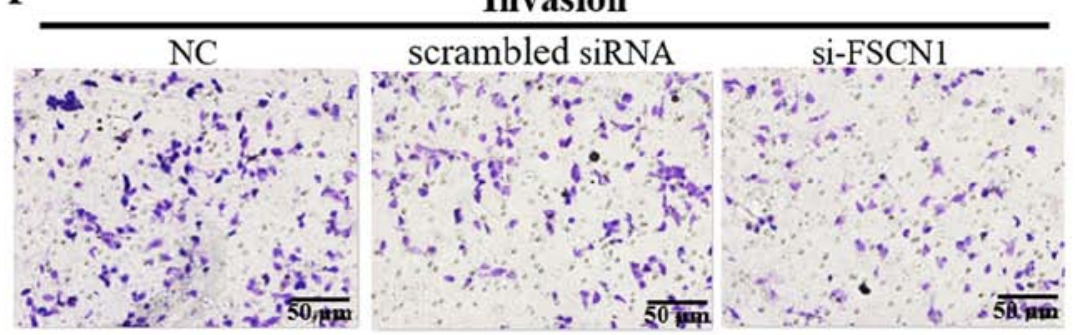

B

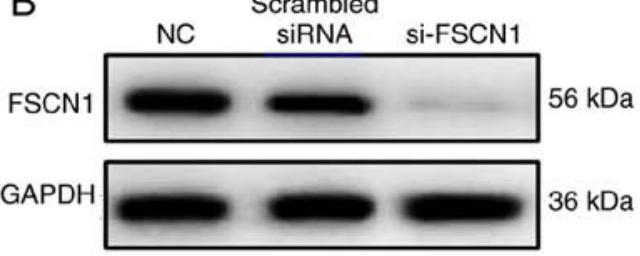

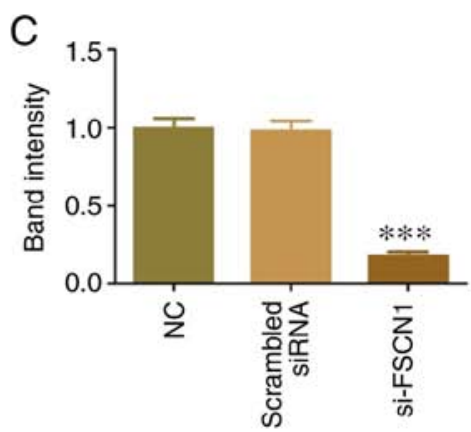

E

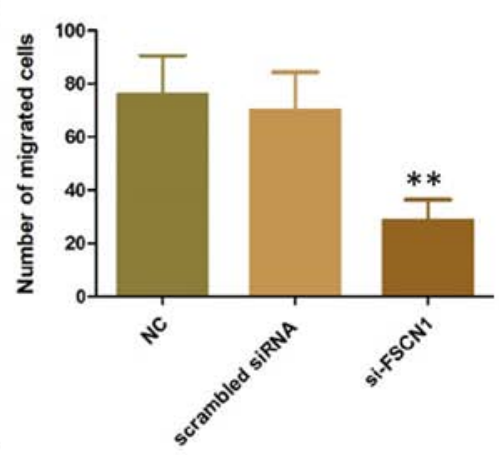

G

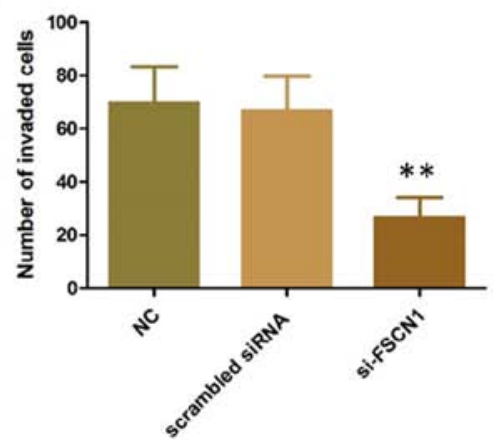

Figure 6. FSCN1 siRNA inhibited the migration and invasion of cervical cancer. FSCN1 siRNA suppressed the (A) mRNA and (B and C) protein expression of FSCN1 in HeLa cells. Knockdown of FSCN1 suppressed the (D and E) migration and (F and G) invasion of HeLa cells with Transwell assays. Magnification, x40. ${ }^{*} \mathrm{P}<0.05,{ }^{* *} \mathrm{P}<0.01$ and ${ }^{* * *} \mathrm{P}<0.001$ vs. NC. FSCN1, fascin; siRNA, small interfering RNA; NC, negative control.

proliferation and migration of Hep-2 cells by suppressing FSCN1 expression to induce cell cycle arrest and apoptosis (25). The present study showed that the expression levels of miR-145-5p were significantly decreased in CC tissues and cell lines, but FSCN1 levels were significantly increased in these tissues and cells. Meanwhile, it was found that miR-145-5p targeted FSCN1 and regulated its expression using luciferase reporter assays, suggesting that FSCN1 is a target of miR-145-5p in CC.

FSCN1, an actin-connecting protein, are present in mesenchymal tissues but is downregulated in adult epithelial cells (14). FSCN1 stabilizes the generation of parallel actin bundles in cell-protruding areas during the early phase of cell movement in physiological and neoplastic conditions (15). FSCN1 is expressed in various epithelial and non-epithelial neoplasms, but it is overexpressed in malignant cells, especially at deep tumor margins (26). FSCN1 is overexpressed in most cervical intraepithelial neoplasia (CIN) lesions, which may indicate increased invasion in high grade CIN, indicating that FSCN1 could have value as a diagnostic biomarker of superficial stromal invasion (27). The present study reported that knockdown of miR-145-5p promoted the expression of FSCN1 in HeLa and ECT1/E6E7 cells; however, overexpression of miR-145-5p repressed the expression of FSCN1. In addition, the migration and invasion of HeLa and ECT1/E6E7 cells were enhanced by the overexpression of miR-145-5p but suppressed by the downregulation of this miRNA. A previous study reported that the inhibition of FSCN1 decreased the activity of the MAPK pathway and suppressed the growth and metastasis of non-small cell lung cancer (NSCLC) cells, indicating that it may be a potentially effective therapeutic strategy for treating NSCLC (28). In addition, FSCN1 is an important mediator of TGF- $\beta 1$-induced invasion and migration of kidney cancer cells (KCC) via ERK and JNK signaling pathways (29). FSCN1 could act as an oncogene and a potential novel prognostic biomarker for patients with renal cell carcinoma (RCC) after nephrectomy, and can promote RCC metastasis (30). However, the signaling pathway of FSCN1 involved in $\mathrm{CC}$ is still unclear and will be investigated in future studies. 
A

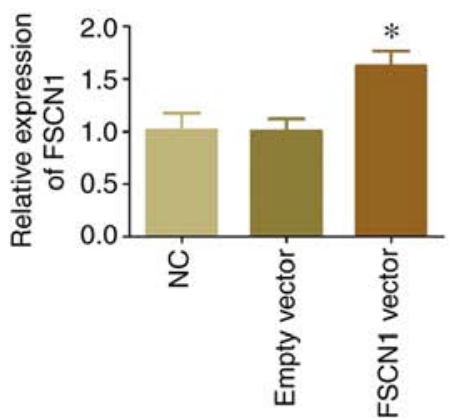

D

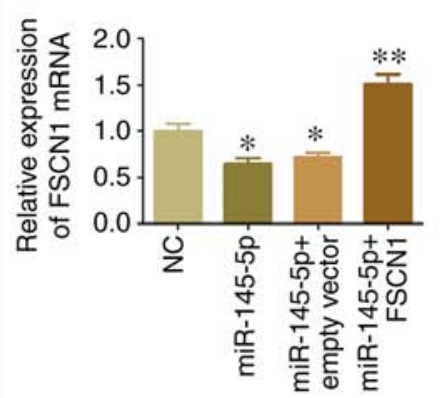

B

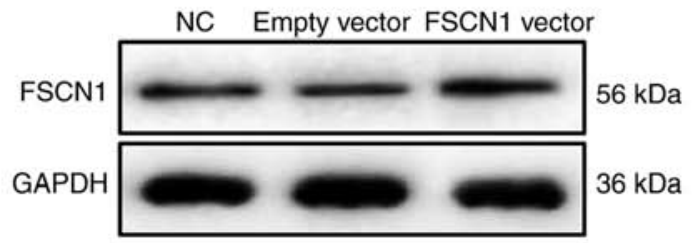

C

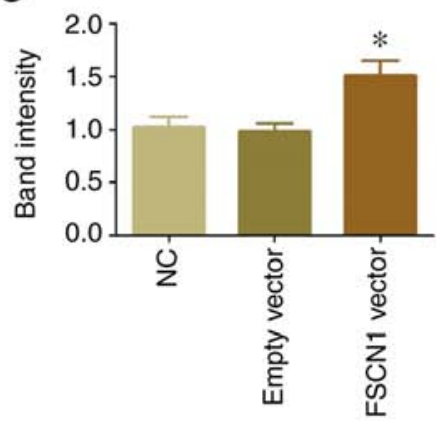

F

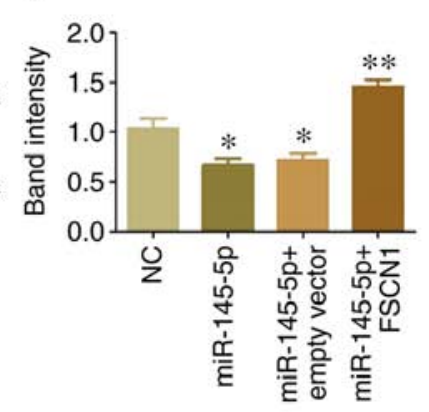

G

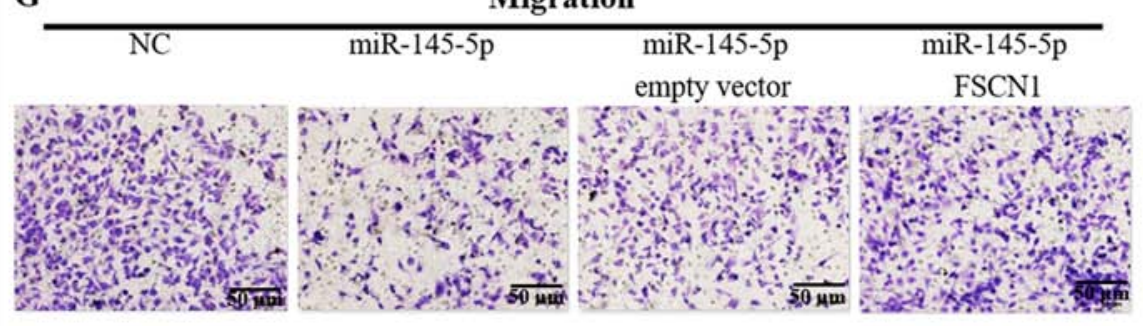

I

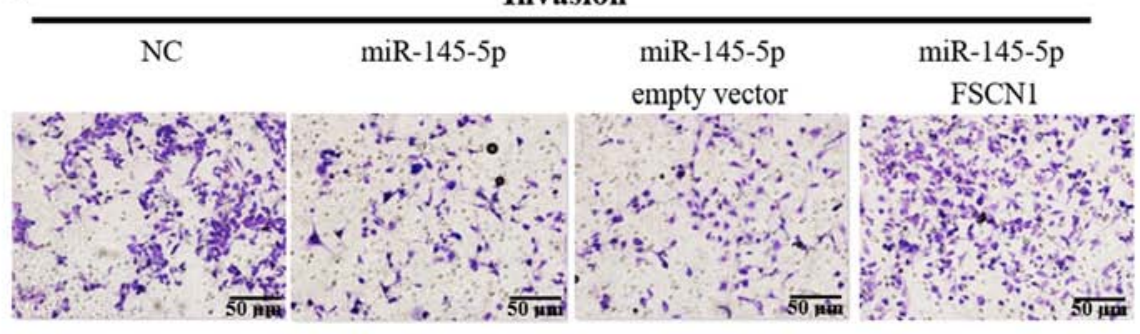

$E$

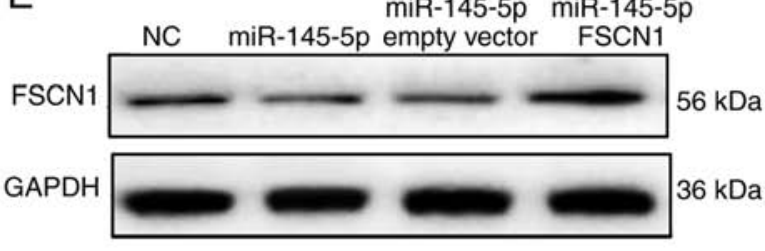

H
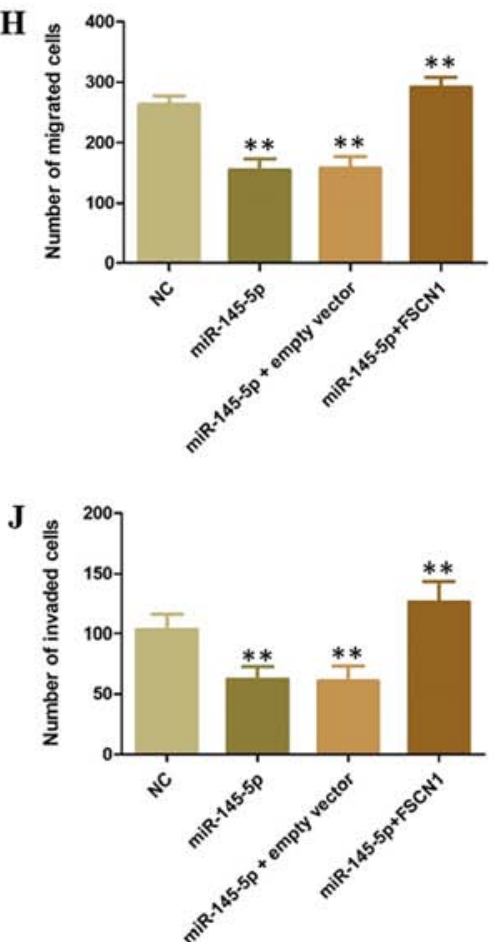

Figure 7. FSCN1 regulates the tumor-suppressive function of miR-145-5p. The (A) mRNA and (B and C) protein expression of FSCN1 in HeLa cells transfected with empty vector and FSCN1 expression vector. The expression of FSCN1 (D) mRNA and (E and F) protein in HeLa cells treated with miR-145 mimics with FSCN1 expression vector or empty vector. (G and H) Migration and (I and J) invasion assays conducted in HeLa cells treated with miR-145-5p and FSCN1 overexpression vector. Magnification, $\mathrm{x} 40 .{ }^{*} \mathrm{P}<0.05$ and ${ }^{* *} \mathrm{P}<0.01$ vs. NC. FSCN1, fascin; miR, microRNA; NC, negative control.

In summary, miR-145-5p overexpression significantly inhibited the proliferation, migration and invasion of $\mathrm{HeLa}$ and ECT1/E6E7 cells, and silencing of FSCN1 expression similarly restricted the proliferation, migration and invasion of these cells. The miR-145/FSCN1 axis facilitated the progression of $\mathrm{CC}$ by restricting $\mathrm{CC}$ cell proliferation.
However, the present study did not assess the function of miR-145-5p-targeted FSCN1 in animal experiments. Follow-up studies will focus on their functions in animal models. Overall, the present findings may provide insight for further studies investigating the effects of miR-145-5p functions and underlying mechanisms on the biological behavior of CC. 


\section{Acknowledgements}

Not applicable.

\section{Funding}

No funding was received.

\section{Availability of data and materials}

The datasets used and/or analyzed during the current study are available from the corresponding author on reasonable request.

\section{Authors' contributions}

SH and SL designed all the experiments, drafted and revised this manuscript. SH, GY and KP performed the experiments and analyzed all data. All authors read and approved the final manuscript.

\section{Ethics approval and consent to participate}

The present study was approved by the Ethics Committee of the First Affiliated Hospital of Nanchang University (approval no. 2018023). Written informed consent was obtained from all patients.

\section{Patient consent for publication}

Not applicable.

\section{Competing interests}

The authors declare that they have no competing interests.

\section{References}

1. Bray F, Ferlay J, Soerjomataram I, Siegel RL, Torre LA and Jemal A: Global cancer statistics 2018: GLOBOCAN estimates of incidence and mortality worldwide for 36 cancers in 185 countries. CA Cancer J Clin 68: 394-424, 2018.

2. Yu Y, Zhang Y and Zhang S: MicroRNA-92 regulates cervical tumorigenesis and its expression is upregulated by human papillomavirus-16 E6 in cervical cancer cells. Oncol Lett 6: 468-474, 2013.

3. Park TW, Fujiwara $\mathrm{H}$ and Wright TC: Molecular biology of cervical cancer and its precursors. Cancer 76 (10 Suppl) S1902-S1913, 1995.

4. Peiretti M, Zapardiel I, Zanagnolo V, Landonia F, Morrowc CP and Maggionia A: Management of recurrent cervical cancer: A review of the literature. Surg Oncol 21: e59-e66, 2012.

5. Li N, Cui T, Guo W, Wang D and Mao L: MiR-155-5p accelerates the metastasis of cervical cancer cell via targeting TP53INP1. Onco Targets Ther 12: 3181-3196, 2019.

6. Farazi TA, Hoell JI, Morozov P and Tuschl T: MicroRNAs in human cancer. Adv Exp Med Biol 774: 1-20, 2013.

7. Pardini B, De Maria D, Francavilla A, Di Gaetano C, Ronco G and Naccarati A: MicroRNAs as markers of progression in cervical cancer: A systematic review. BMC Cancer 18: 696, 2018.

8. Iorio MV, Ferracin M, Liu CG, Veronese A, Spizzo R, Sabbioni S, Magri E, Pedriali M, Fabbri M, Campiglio M, et al: MicroRNA gene expression deregulation in human breast cancer. Cancer Res 65: 7065-7070, 2005.

9. Iorio MV, Visone R, Di Leva G, Donati V, Petrocca F, Casalini P, Taccioli C, Volinia S, Liu CG, Alder H, et al: MicroRNA signatures in human ovarian cancer. Cancer Res 67: 8699-8707, 2007.
10. Takagi T and Iio AY: Decreased expression of microRNA-143 and -145 in human gastric cancers. Oncology 77: 12-21, 2009

11. Liu X, Sempere LF, Galimberti F, Freemantle SJ, Black C, Dragnev KH, Ma Y, Fiering S, Memoli V, Li H, et al: Uncovering growth-suppressive MicroRNAs in lung cancer. Clin Cancer Res 15: 1177-1183, 2009.

12. Li C, Xu N, Li YQ, Wang Y and Zhu ZT: Inhibition of SW620 human colon cancer cells by upregulating mi RNA-145. World J Gastroenterol 22: 2771-2778, 2016.

13. Zhang J, Wang L, Li B, Huo M, Mu MU, Liu J and Han J: miR-145 downregulates the expression of cyclin-dependent kinase 6 in human cervical carcinoma cells. Ther Med 8: 591-594, 2014.

14. Hashimoto Y, Skacel M and Adams JC: Roles of fascin in human carcinoma motility and signaling: Prospects for a novel biomarker? Int J Biochem Cell Biol 37: 1787-804, 2005.

15. Li A, Dawson JC, Forero-Vargas M, Spence HJ, Yu XZ, König I, Anderson K and Machesky LM: The actin-bundling protein fascin stabilizes actin in invadopodia and potentiates protrusive invasion. Curr Biol 20: 339-345, 2010.

16. Liu R, Liao J, Yang M, Sheng J, Yang H, Wang Y, Pan E, Guo W, $\mathrm{Pu}$ Y, Kim SJ and Yin L: The cluster of miR-143 and miR-145 affects the risk for esophageal squamous cell carcinoma through co-regulating fascin homolog 1. PLoS One 7: e33987, 2012.

17. Zhang M, Dong BB, Lu M, Zheng MJ, Chen H, Ding JZ, Xu AM and $\mathrm{Xu}$ YH: miR-429 functions as a tumor suppressor by targeting FSCN1 in gastric cancer cells. Onco Targets Ther 9: 1123-1133, 2016.

18. Li J, Lu J, Ye Z, Han X, Zheng X, Hou H, Chen W, Li X and Zhao L: 20(S)-Rg3 blocked epithelial-mesenchymal transition through DNMT3A/miR-145/FSCN1 in ovarian cancer. Oncotarget 8: 53375-53386, 2017.

19. Chen JJ, Cai WY, Liu XW, Luo QC, Chen G, Huang WF, Li N, Cai JC and Yang CF: Reverse correlation between MicroRNA-145 and FSCN1 affecting gastric cancer migration and invasion. PLoS One 10: e012690, 2015

20. Ma L and Li LL: miR-145 Contributes to the progression of cervical carcinoma by directly regulating FSCN1. Cell Transplant 28: 1299-1305, 2019.

21. Livak KJ and Schmittgen TD: Analysis of relative gene expression data using real-time quantitative PCR and the 2(-Delta Delta C(T)) method. Methods 25: 402-408, 2001.

22. Bartel DP: MicroRNAs genomics, biogenesis, mechanism, and function. Cell 116: 281-297, 2004.

23. Iorio MV and Croce CM: MicroRNAs in cancer: Small molecules with a huge impact. J Clin Oncol 27: 5848-5856, 2009.

24. Slattery ML, Herrick JS, Mullany LE, Valeri N, Stevens J, Caan BJ, Samowitz W and Wolff RK: An evaluation and replication of miRNAs with disease stage and colorectal cancer-specific mortality. Int J Cancer 137: 428-438, 2015.

25. Gao W, Zhang C, Li W, Li H, Sang J, Zhao Q, Bo Y, Luo H, Zheng X, Lu Y, et al: Promoter methylation-regulated miR-145-5p inhibits laryngeal squamous cell carcinoma progression by targeting FSCN1. Mol Ther 27: 365-379, 2019.

26. Stewart CJ, Crook M and Loi S: Fascin expression in endocervical neoplasia: Correlation with tumour morphology and growth pattern. J Clin Pathol 65: 213-217, 2012.

27. Koay MH, Crook M and Stewart CJ: Fascin expression in cervical normal squamous epithelium, cervical intraepithelial neoplasia, and superficially invasive (stage IA1) squamous carcinoma of the cervix. Pathology 46: 433-438, 2018.

28. Zhao D, Zhang T, Hou XM and Ling XL: Knockdown of fascin-1 expression suppresses cell migration and invasion of non-small cell lung cancer by regulating the MAPK pathway. Biochem Biophys Res Commun 497: 694-699, 2018.

29. Yang J, Zhang N, Gao R, Zhu Y, Zhang Z, Xu X, Wang J, Li Z, Liu X, Li Z, et al: TGF- $\beta 1$ induced fascin1 expression facilitates the migration and invasion of kidney carcinoma cells through ERK and JNK signaling pathways. Biochem Biophys Res Commun 501: 913-919, 2018.

30. Zhang M, Zhao Z, Duan X, Chen P and Peng Z, Qiu H: FSCN1 predicts survival and is regulated by a PI3K-dependent mechanism in renal cell carcinoma. J Cell Physiol 233: 4748-4758, 2018.

This work is licensed under a Creative Commons Attribution-NonCommercial-NoDerivatives 4.0 International (CC BY-NC-ND 4.0) License. 